\title{
メタノール分解ガスと軽油の二燃料ディーゼル機関*
}

\author{
是松孝治*1, 雑 賀 高*1, 伊藤 光一郎*2
}

\section{Dual Fueled Diesel Engine with Dissociated Methanol and Gas Oil}

\author{
Koji KOREMATSU, Takashi SAIKA, and Koichiro. ITO
}

\begin{abstract}
This paper presents the results of performance testing of a dual fueled diesel engine with dissociated methanol and gas oil. The engine system equipped with a methanol dissociation reactor has a potential for improving the engine system efficiency, because the reaction of methanol dissocia. tion is endothermic and the energy required for the reaction is supplied by the exhaust waste heat. However the presence of knock, misfire and poor combustion of the premixed dissociated methanol -air mixture prevent the extraction of this potential of the engine system. It is concluded from the test results that we can get higher efficiency and a lower smoke level than the original engine if the proper methanol/gas oil ratio and injection timing are selected as operating conditions to avoid the above undesirble phenomena.
\end{abstract}

Key Words: Diesel Engine, Combustion, Methanol Fuel, Waste Heat Recovery, Dissociated Methanol

\section{1. 緒}

石油代替あるいは排ガス特性の改善という視点か ら、内燃機関用然料としてメタノールが注目されてい る.これに伴って、メタノールの特性に立脚した技術 が検討されつつある.その一つに，排気ガスの熱でメ タノールを分解した後に，機関で燃焼させる方法があ る.メタノールは適切な触媒下で加熱されると, 水素 と一酸化炭甞に分解する. 理論的には, $1 \mathrm{~mol} の メ タ$ ノールから $2 \mathrm{~mol}$ の水素と $1 \mathrm{~mol}$ の一酸化炭素を生 ずる.この分解ガスは,メタノールに比へて 1.2 倍の 低発熱量を有している。このことは，分解反応が吸熱 反応であることを意味している、したがって大気に放 出される排気ガスの熱を反応熱として供給すれば、こ の分だけ熱効率が改善されることになる.メタノール を、このようなシステムで利用する試みは，火花点火 機成に对してはすでに研究が行われてきたが(1)〜7)，デ イーゼル機関に対しては、ごく最近になって研究が進 められている状況にあり ${ }^{(8) \sim(10)}$, 多くの実証データが 必要でるように見受けられる。

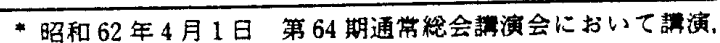
原稿受付 昭和 61 年 6 月 25 日.

*1 正買. 工学院大学 (-160 東京都新宿区西新宿 1-24-2).

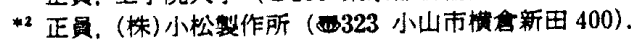

そこで著者らは、排気ガスの熱を利用して発生させ たメタノール分解ガスを吸気に混入するとともに，軽 油を噴射系で供給し着火させるディーゼル機関システ 厶を試作し，その性能を調べ効果的な運転方法を明ら かにしたので報告する。

\section{2. 实験装置と実験方法}

図 1 は，実験に用いた機関システムの榑成と測定系 を示している、メタノールは、然料ポンプで圧送され 噴射弁を通して蒸発器に供給される。蒸発器は基本的 には，排気ガスの熱をメタノールに伝える多管式熱交 換器であり、その伝熱面稿は $0.64 \mathrm{~m}^{2}$ である.メタノー ル蒸気は反応器で分解され，機関の吸気管に供給され ろ.このとき, 各シリンダに供給される混合気のメタ ノ一ル分解ガス䙉度が均一となるようにするため,メ タノール分解ガスの流入方向を吸気弁と反対側に選ん ている. 反応器も基本的には多管式熱交換器であり, 内径 $\phi 13.8 \mathrm{~mm}$, 長さ $246 \mathrm{~mm}$ の円管内に封入されて いるペレット形の $\mathrm{Pt}-\mathrm{Al}_{2} \mathrm{O}_{3}$ 触媒にメタノール蒸気を 接触させることにより, 水索と一酸化炭索に分解しょ うとしている。一方，着火源となる軽油は通常の噴射 系で与えている。また実験機関の仕様は, 表 1 に示す とおりであり，本質的な改造は施していない。 
機関の運転は，回転速度と出力を一定に保ちつつ， 軽油とメタノールの比率を変化させる方法を用いる。 このように運転されている機関の動力性能，筒内圧力 経過ならびに排気ガス特性を調べる。於実際の測定 では, 排気系の温度が安定していることを確認するよ う特に留意している。

\section{3. 実㬇結果と考察}

3.1 メタノール分解反応器の特性 メタノール の分解に対する $\mathrm{Pt}-\mathrm{Al}_{2} \mathrm{O}_{3}$ 触媒の有奻性については， すでに述べられている(1)(4).ここでは，機関に実装され た状態における特性を明らかにしておく，供給したメ タノールの質量に対する発生ガスの質量の比率を意味 するガス化率の測定結果を図 2 に示す。このガス化率 は，以下の上うにして求めている．まず機関を軽油の みで運転するとともに，蒸発器にメタノールを送る。 反応器から流出するガスは，吸気管に供給するのでは なく, 別置の水冷式冷却器に導き凝縮分をトラップす る．供給したメタノールの筫量から，この凝縮分を差 引いてガスの質量を定め，ガス化率を算出する。この 実験ては，冷却水温 $10 \pm 2^{\circ} \mathrm{C} て ゙$ 行っており，この温度 に対する飽和蒸気圧分がトラップされずに通過するこ とが考えられるが，これに伴う誤差は最大 $4 \%$ 程度と 見掼もれる. また図 2 の横軸の反応器の代表温度は， 反応器の中央部の触媒圈の温度をとっている。この温 度は，機関の負荷と回転速度を変えることで制御して いる.

図 2 の実験結果を見ると，代表温度の上昇に伴って

表 1 供試ディーゼル機関諸元

\begin{tabular}{|l|l|}
\hline Model & KOMATSU 4092 \\
\hline Type of engine & Direct in jection \\
\hline Bore X Stroke & $105 \mathrm{~mm} \times 125 \mathrm{~mm}$ \\
\hline Stroke volume & $2600 \mathrm{c}$. \\
\hline $\begin{array}{l}\text { Rated output } \\
\text { (diesel oil) }\end{array}$ & $37.3 \mathrm{~kW} / 2800 \mathrm{rpm}$ \\
\hline
\end{tabular}

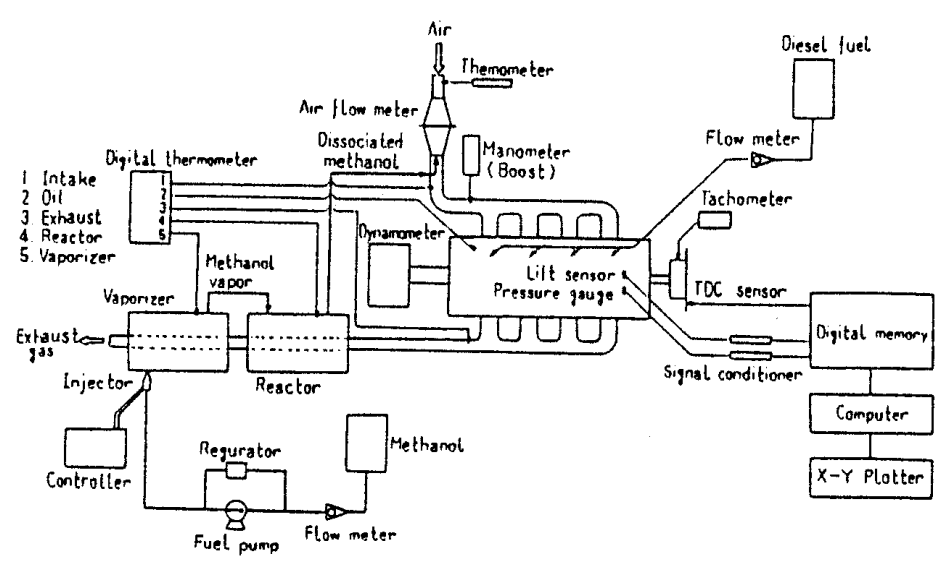

図 1 機関システムと測定系
ガス化率が高くなっている．またメタノール流量を增 加させて，空間速度の值を大きくするとガス化率はゃ や減少しているが，空間速度による支配的な閶係は見 られない。このことは，実装した反応器は反応を完結 するのにほほ十分な大きさがあり，ガス化率は温度分 布や温度の絶対値に支配されることを示している。 たガスクロマトグラフィーを用いて，分解がスの成分 分析を行うと表 2 のううになる．高温になるとメタン の生成量がやや多くなるが,メタノールが水素と一酸 化炭素に分解する主反応が支配的であることがわか る.

3.2 機関システムの各理性能図 3 は, 平均有 効圧を $0.28 \mathrm{MPa}$ あるいは $0.51 \mathrm{MPa} に$ に保って, 低発 熱量基準の全燃料中のメタノール率 $f_{m}$ ，すなわち

$$
f_{m}=\frac{\dot{M}_{m} q_{m}}{\dot{M}_{m} q_{m}+\dot{M}_{o} q_{s}}
$$

の値を変化させた場合の各種性能の測定結果である。 式(1)中の $\dot{M}_{m}$ 怯給しているメタノールの穓量流 量 $[\mathrm{kg} / \mathrm{s}], \dot{M}_{g}$ は供給している軽油の筫量流量 $[\mathrm{kg} /$ $\mathrm{s}], q_{m}$ はメタノールの低発熱量 $[\mathrm{MJ} / \mathrm{kg}], q_{g}$ は軽油の 低発熱量を表している。

$3 \cdot 2 \cdot 1$ 熱消费率 機関システム全体のエネルギ 経済性の評価は, $1 \mathrm{~kW}$ の軸出力を発生するのに要す る低発熱量基準のメタノールと軽油の単位時間あたり の供給熱量 $[\mathrm{MJ} / \mathrm{h}]$ を意味する熟消率 BSHC $[\mathrm{MJ} /$ $\mathrm{kWh}$ ]で行う. 単純に考えると反応器温度に支配され るガス化率とメタノール率 $f_{m}$ の值に応じて, 排気熱 回収効果が現れ，BSHCの値が下がり性能が向上する はずである.しかし，図 $3(\mathrm{a})$ の平均有効压 $0.28 \mathrm{MPa}$

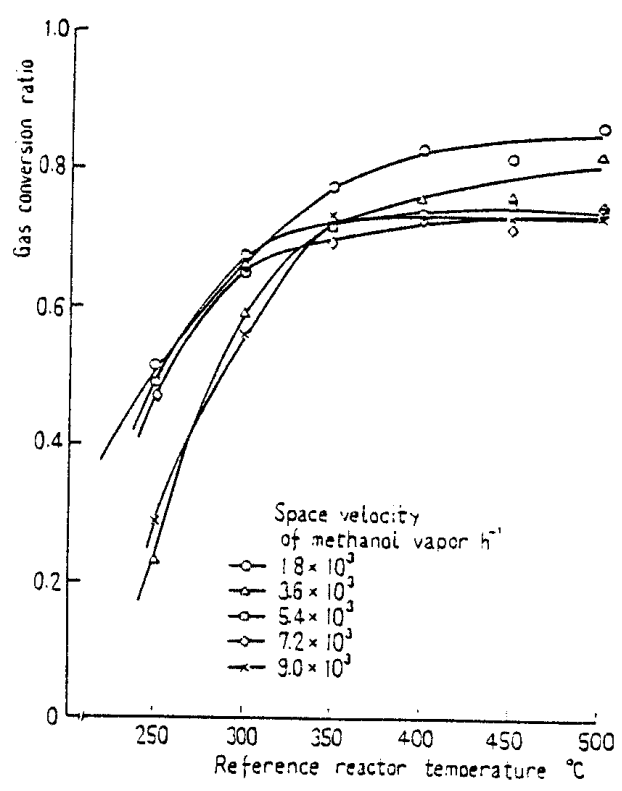

図 2 メタノール分解反応器の特性 
の結果を見ると， $f_{m}$ の增大とともに BSHCの值が増 加している.このときの反応器温度は $230 \sim 250^{\circ} \mathrm{C} て ゙$ あり,ガス化率は 0.1 0.5 程度と見積もれる.すなわ ち，ある程度の排気熱回収効果があるにもかかわらず， 熱消費率が墨化したことになる。これに対して, 図 3 (b)の平均有効圧 $0.51 \mathrm{MPa} の$ 場合には, $f_{m}$ が 0.45 程度までは確かに $f_{m}$ の增大に伴って BSHCの值が低 下し性能が向上している.しかし， $f_{m}$ の值をこれより 大きくすると BSHC の值は, 急激に増加してくる。こ れらの実験結果について，以下のように考察する.

（1）メタノール分解ガス一空気混合気の燃焼限界 と熱消費率図 3（a）のように比較的負荷の低い領 域で, BSHCの改善効果が現れなかった理由について 考えてみる.排気中の $\mathrm{CO}$ 濃度の測定結果に注目して みると, $f_{m}$ の增大に伴って $\mathrm{CO}$ 濃度が単調に増加して いることかわかる。これは，吸気管から供給している メ夕ノール分解ガス中の COが，燃焼せずそのまま排 出されることを示すものである．熱消費率の悪化の程 度は，燃焼室内を単に通過したメタノール分解ガスの 量に対応することになり， $f_{m}$ の増加とともに単調に
BSHCが増加する測定結果を裹付けている。

一方, 負荷が比較的高い図 3 (b)の CO 灌度の測定 結果を見ると， $f_{m}$ が増加すると初めは $\mathrm{CO}$ 摆度は高く なるが, $f_{m}$ が約 0.4 になると $0.25 \%$ 程度まで低下し， さらに $f_{m}$ を大きくすると $0.20 \%$ 程度まて低下して いく. CO 濃度の絶対值は, 図 3 (a)よりも大きいが, 供給しているメタノール量が多いことと反応器温度が 高くガス化率が高いのて，吸気中の CO 濃度が1オー ダ高いことを考慮すると、供給したメタノール分解ガ スの大部分が燃焼していると考えられる。このことは， メ夕ノール率 $f_{m}$ が 0.4 程度までは, $f_{m}$ の増加に伴っ て BSHCが隇少している実験結果を裹付けるもので ある， $f_{m}$ をさらに大きくすると，本項 $(2)$ で述べるよ うに,ノックの発生によって BSHC は増加してしま う.

いずれにしても，排気熱回収が行われ，しかも予混 合供給されるメ夕ノール分解ガスの大部分が燃焼する かどうかが, BSHC 改善のポイントとなる。この場合, 軽油にエントレイメントされたメタノール分解ガスは 容易に燃焼すると考えられるので，それ以外の領域が

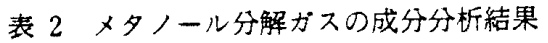

\begin{tabular}{|c|c|c|c|c|}
\hline \multirow[t]{2}{*}{$\begin{array}{l}\text { Referance reactor } \\
\text { temperature o }\end{array}$} & \multicolumn{4}{|c|}{$\begin{array}{l}\text { Chemical composition of dissociated methanol } \\
\text { (only in gas phase) Mole fraction }\end{array}$} \\
\hline & $-\mathrm{H}_{2}$ & co & $\mathrm{CH}_{4}$ & Ochers \\
\hline 250 & 0.630 & 0.283 & 0.025 & 0.062 \\
\hline $\begin{array}{l}350 \\
450\end{array}$ & $\begin{array}{l}0.641 \\
0.640\end{array}$ & 0.292 & 0.037 & 0.030 \\
\hline
\end{tabular}
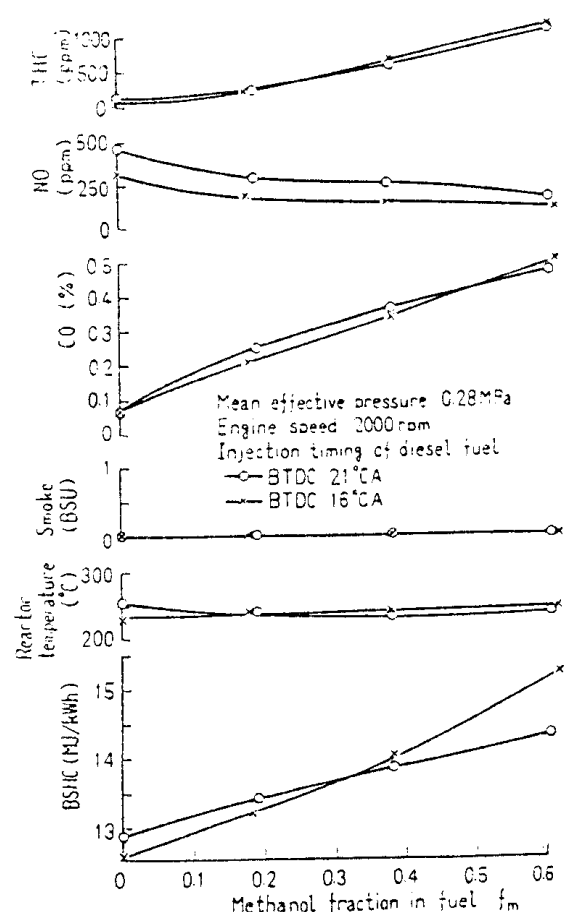

(a) 正味平均有効王 $0.28 \mathrm{MPa}$
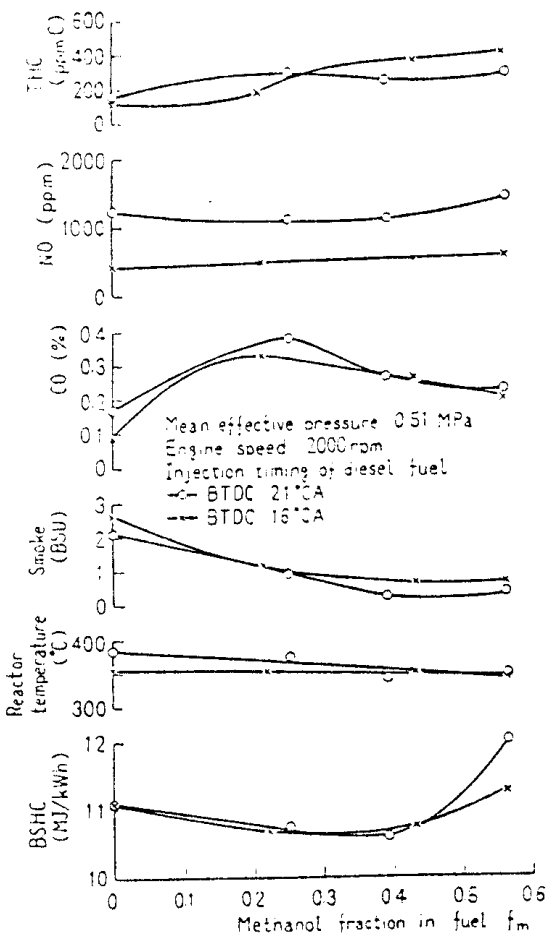

(b) 正味平均有効压 $0.51 \mathrm{MPa}$

困 3 機関システムの各種性能に対するメタノール率の影哓 
然燒するかが問題となる，直接噴射式ディーゼル機関 において，気体然料を吸気管から供給したOhta ら(11), Varda ${ }^{(12)}$, Bro ら ${ }^{(13)} の$ 研究によると, 軽油噴蓩のまわ りの気体燃料が燃焼するためには，混合気瀑度が下限 界を超えて可燃範囲に入っていることが必要であると 指摘されている。

本実験の場合の下限界は, 以下のようにして計算す る.メタノール分解ガス中の水素, 一酸化炭素, メタン およびメタノール蒸気のモル比を $n_{\mathrm{H}_{2}}, n_{\mathrm{CO},}, n_{\mathrm{CH}}$, $n_{\mathrm{CH}_{3} \mathrm{OH}}$ とし, それそれの下限界を $L_{\mathrm{H}_{2}}, L_{\mathrm{Co}}, L_{\mathrm{CH}_{4}}$, $L_{\mathrm{CH}_{3} \mathrm{OH}}$ とすると,メタノール分解ガスの下限界 $L$ は, Le Chatelierの式により ${ }^{(14)}$,

$$
L=100 /\left(\frac{n_{\mathrm{H}_{2}}}{L_{\mathrm{H}_{2}}}+\frac{n_{\mathrm{CO}}}{L_{\mathrm{CO}}}+\frac{n_{\mathrm{CH}_{4}}}{L_{\mathrm{CH}_{2}}}+\frac{n_{\mathrm{CH}_{3} \mathrm{OH}}}{L_{\mathrm{CH}_{3} \mathrm{OH}}}\right) \cdots
$$

となる. $n_{\mathrm{H}_{2}}, n_{\mathrm{CO},} n_{\mathrm{CH}_{4},} n_{\mathrm{CH}_{3} \mathrm{OH}}$ の值はガス化率と成分分 析の結果を用いて計算するが，凝縮分はすべてメ夕， ールとし，ガス中の微小他成分は無視している. $25^{\circ} \mathrm{C}$

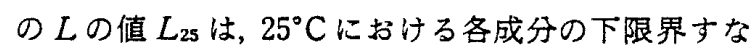
力 $5 L_{\mathrm{H}_{2}}=4.00 \%, L_{\mathrm{CO}}=12.50 \%, L_{\mathrm{CH}_{4}}=5.00 \%$, $L_{\mathrm{CH}_{3} \mathrm{OH}}=6.72 \%$, 式( 2$)$ に代入して求めることがで きる.しかし, 軽油噴蔈着火時のメタノール分解ガスー 空気混合気は, 圧縮され温度と圧力が上昇しているの で, その下限界は $L_{25}$ とは異なる。 そこで筒内圧力経 過から，噴射開始時のメタノール分解ガス一空気混合

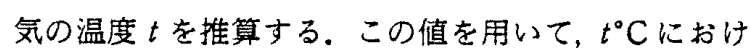
ろ下限界 $L_{t}$ をZ Zabetakis の式(14)

$$
L_{t}=L_{25}-\frac{0.18}{\Delta H_{c}}(t-25)
$$

から求める.ここに $\Delta H_{c}$ は，メタノール分解ガスの燃 燒熱である．さらに㛜密に言えば，圧力の補正も必要 であるが，一般に圧力の効果は小さいことと適正なデ 一タがないので,ここでは省略している。

図 4 はメタノール率 $f_{m}$ を一定にして, 正味平均有 効圧を変化させたときの吸気中の燃料濃度と下限界の 計算值を比較したものである。平均有効圧の上昇は燃 料の供給量の增大を意味するのて， $f_{m}$ 一定で平均有 効圧が上昇すれば吸気に混入しているメタノール分解 ガス濃度は高くなる.これに対して下限界は, 平均有 効圧の上昇に伴って低濃度側に移っていく，この理由 は, 平均有効圧が上昇すると排気温度が高くなりガス 化率が上がり水素成分が多くなることと，温度が高く なって下限界が抎大するためである、いま図40吸気 中の燃料濃度の曲線と下限界の曲線の交点に注目す ろ.この交点は, 問題となっている軽油噴菻の着火・ 燃焼に続いて，そのまわりの予混合気が燃焼するかど うかの限界を与えている. $f_{m}$ の值が大きいと平均有効
圧の值が低くても，予混合供給のメタノール分解ガス が然焼することになる. 図 4 において, 平均有効圧 $0.28 \mathrm{MPa}$ の点をみると, $f_{m}$ を0.5にしてもメタノー ル分解ガス濃度は下限界に達しないことがわかる。こ れは， $f_{m}$ の増加とともにBSHC が增加する図 3(a) の結果が, 軽油噴霧まわりのメタノール分解ガスが然 焼しないためであることを裹付けるものである、これ に対して，図 4 で平均有効圧が $0.51 \mathrm{MPa}$ の点をみる と, $f_{m}$ の值が 0.2 であっもメタノール分解ガス簧 度は下限界に達する。したがって図 3(b)の場合は, 軽油噴裙まわりのメタノール分解ガスは燃燒している ものと考えられる。すなわち本機関システムにおいて， 軽油噴蓩の燃焼に引き続いて，メタノール分解ガスー 架気混合気が燃焼するためには，その嶩度が可燃範囲 に入ることが必要であり，その見積もりは指圧図から 求めた軽油噴射開始時の温度と式 (2)，(3)で行うこ とができる。

（2）ノック限界と熱消費率吸気に混入する燃 料量を增していくと, 最高圧力ょよび圧力上昇率が高 くなりノックを生じることが知られている(11)〜(13)， ック限界に近づくと, 主として熱損失が增大するため 熱消費率は悪化する. 図 3 (b)でメタノール率を 0.57 とすると，メタノール分解ガス濃度は下限界を超えて いるにもかかわらず, BSHCの值が軽油単味運転の場 合より高くなったのは，このためである。図 5 に示す シリンダ内最高圧力 $p_{\max }$,最大圧力上昇率 $(d p / d \theta)_{\max }$ の測定結果を見ると,メタノール率 $f_{m}$ の増大に伴っ て $p_{\max }(d p / d \theta)_{\max }$ ともに增加していることがわかる. 正味平均有効圧 $0.51 \mathrm{MPa}$ の場合, $f_{m}$ が 0.5 以上に なると $(d p / d \theta)_{\max }$ が急激な增加傾向をもち，ノック限 界に近づいていることが確認される。

図 6 は, シリンダ内圧力経過と熱発生率の結果を示

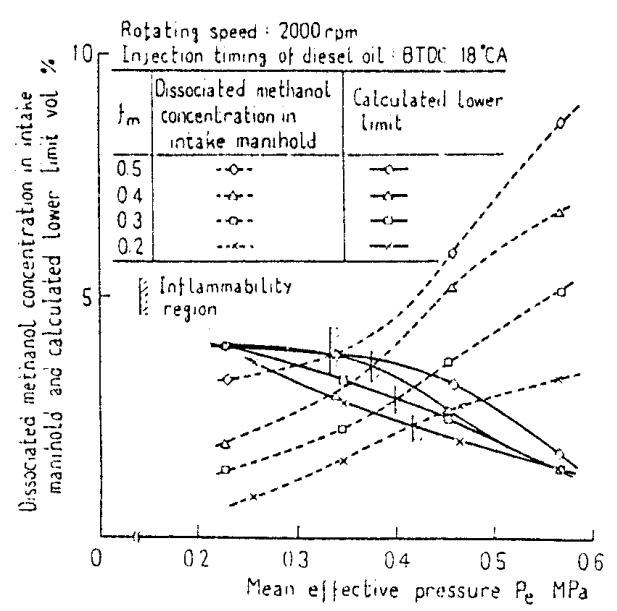

図 4 吸気管内の燃料浱度と下限界の計算值 
している。軽油単味運転に比べて, 着火時期がやや早 くなるとともに予混合燃焼の比率が増加していること がわかる。

図7は各平均有効圧に対して,メタノール率を変化 させてノックによる運転不調限界を求めたものであ る.この運転不調限界は，激しいノック音とともにシ リンダ内压力のサイクル変動が大きくなって,これ以 上メタノール率を上げると機関の停止に至る限界であ る. 判断はやや定性的なものとならざるを得ないが， 再現性は良好である。ノック限界のメタノール率の值 は, 平均有効圧が高いほど小さくなり，回転速度は $2500 \mathrm{rpm}$ よりは $2000 \mathrm{rpm}$ の場合のほうが大きくな る傾向がある。回転速度 $2000 \mathrm{rpm}$ の場合, 平均有効 圧が約 $0.4 \mathrm{MPa}$ 以下の領域では,メタノール率を高 めていくと軽油噴蓩が着火しない失火領域が先に現れ るため,ノックによる運転限界は隠れてしまう。回転 速度 $2000 \mathrm{rpm}$ 一定の条件下で, 軽油の噴射時期を BTDC $16^{\circ}$ から BTDC $10^{\circ}$ に遅らすと, 平均有奻圧 $0.57 \mathrm{MPa}$ 以外の条件でノック限界のメ夕ノール率 の值は大きくなる．このように噴射時期によってノッ クの発生が抑制でること洁, 近久ら ${ }^{(15)}$ の指摘にある 端ガスの自発火に起因する「火花点火ノック」の発生

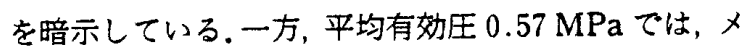
タノール分解ガスおよび軽油とも供給量が多く，初期 然焼の絶対量が多くなって通常のディーゼル機関でお

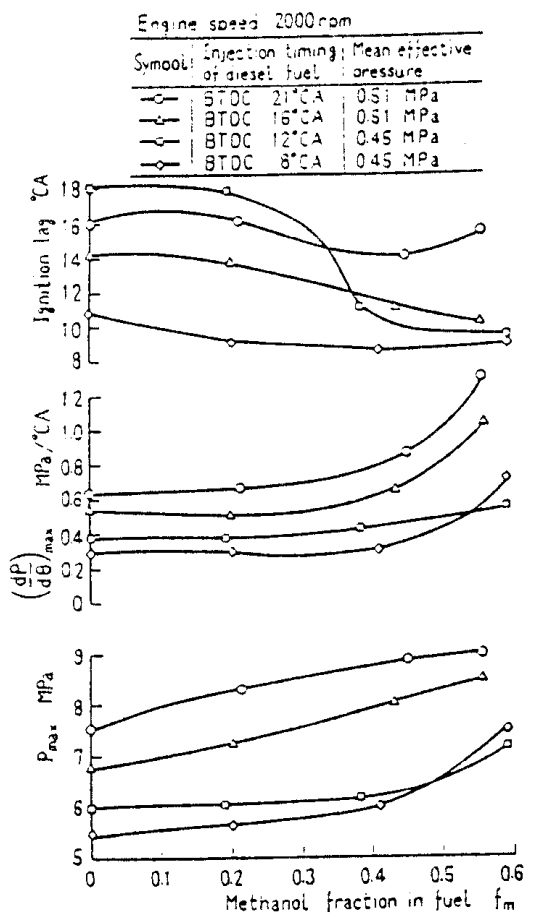

図 5 メタノール率とシリンダ内最高圧力, 最大 王力上昇率, 喤火幄れ
こるノックが発生しているため，嘪射時期を遈らせる ことがノック限界の拡大につながらなかったと解规て きそうである.

3・3 排ガス特性ＣO溜度についてはすでに述 べたので, 全灰化水素䈨度 THCと NOおよびスモー ク漕度（ボッシュ港度）について検討する. 比较的軽 負荷の図 3(a)を見ると, スモーク浩度は轻油単味運 転の場合ても検出されない程度である.THCは,メタ ノール率 $f_{m}$ の增加とともに単調に増加している.こ の原因は，吸気に混入されたメタノール分解ガスが然 焼せず単に燃焼室を通過して排出され，しかも反応器 温度が低く分解反応が十分進まないため分解ガス中に メタノールが含有されているためである。またNO 浱 度は， $f_{m}$ の值を增加させると減少する傾向にある。一 方, 図 $3(\mathrm{~b})$ を見ると $f_{m}$ の増加に伴ってスモーク湿 度は減少している. THC と NO湛度は,メタノール 率と強い相威は認められない.

3.4 機関システムの適正正転城 この機威シス テムの適正な運転域は，軽油による着火が可能であり，

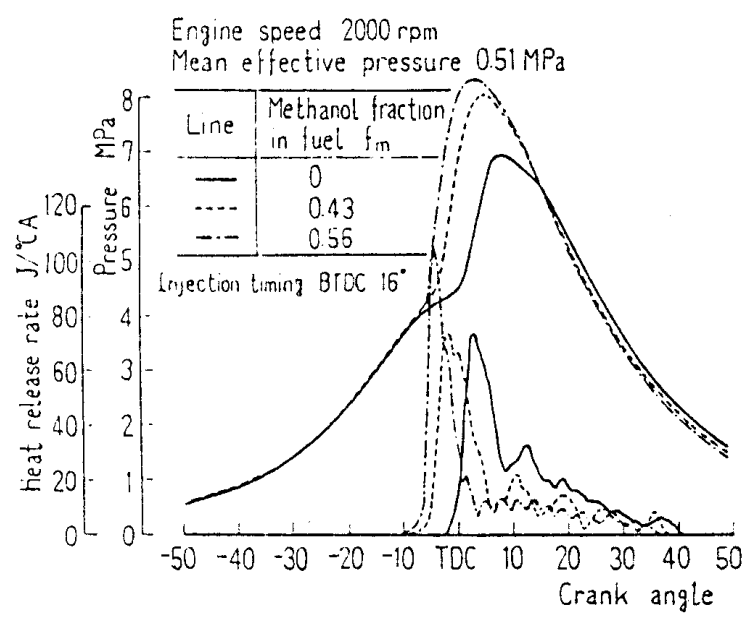

図 6 シリンダ内圧力経過と熱発生率

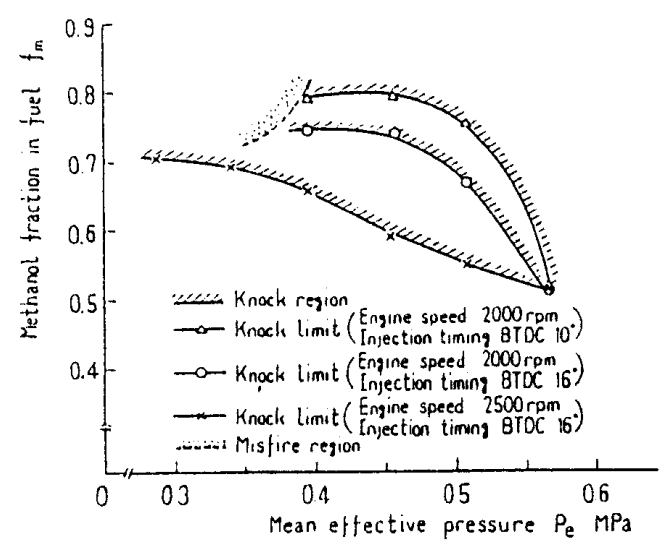

图 7 ノック限界と失火限界 


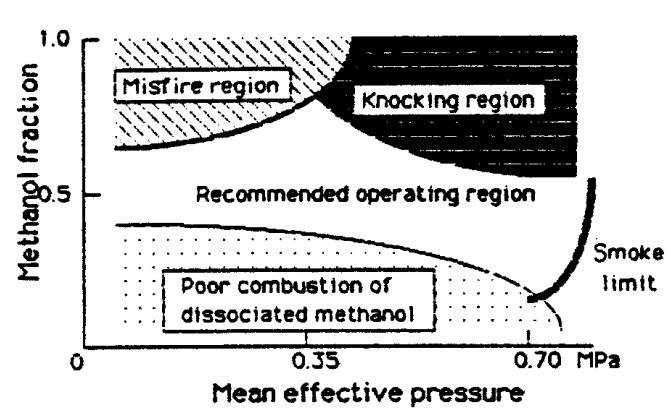

図 8 機開システムの適正連転域概念図

吸気に混入するメタノール分解ガスが可㜣域にあり， ノックが発生せず，スモーク湛度も一定值以下の領域 である.図 8 は，この運転域を概念的に示している。一 般にメタノール率を $0.4 \sim 0.6$ にとると, 比較的広い 負荷範囲で適正運転域となる。

\section{4. 結 嘀}

メタノール分解ガスを吸気に混入するとともに軽油 を噴射し着火させるディーゼル機威の特性を調べ，以 下の主な結論を得た。

（1）試作したメタノール分解反応器のガス化率を 機関システムに組み込んだ状態で調べたところ，反応 器中央部の温度が $230^{\circ} \mathrm{C}$ 程度から分解反応がおこり, 温度か $300^{\circ} \mathrm{C}$ 以上になると，ガス化率は約 $0.6 \sim 0.85$ に達することがわかった。

（2）吸気に混入するメタノール分解ガス湌度が，

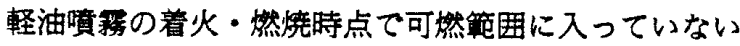
場合には，軽油噴霧にエントレイメントされない領域 の燃焼がおこらないので，排気熱の回収効果はあって も熱消带率は改善されない.
（3）低発熱基㪶の然料中のメタノール率 $f_{m}$ を 増加させていくとノックが発生する。ノック限界に近 づくと熱消费率が悪化するとともに，運転不調となっ ていく.

（4）スモーク湌度は，メタノール率の増加ととも に減少する。THC, CO 湛度は，メタノール率の增加 とともにやや增加する傾向となるが, 軽油䠝霧にエン トレイメントされない領域で予混合供給のメタノール 分解ガスが燃燒すれば增加の程度はわずかとなる。

（5）熱消費率の改善効果が現れ，安定した運転が できる適正運転域は図 8 に示される。

\section{文献}

（1）広田・ほか 2 名，自勒車技術会論文集，20（昭 55)，25.

(2) Finegold, J. G., ほか 2 名. Proc. 4th Int. Sym. Alcohol Fuel Technol., (1980), B-11.

(3) Sjøstrơm, K.. ほか 2 名, SAE Paper, 810348, (1981), 1.

(4) Korematsu, K. and Fukuda, M., Int. J. Energy Syst., 3 $-2,(1983), 48$.

(5) Lindner, B. and Sjöström, K., Proc. 5th Int. Symp. Alcohol Fuel Technol., (1982), 2-85.

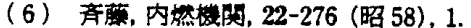

（7）山口・注加 4 名，自娌車技術会論文集，31（昭 60)，29.

(8) Korematsu, K., ほか 4 名, SAE Paper, 831298, (1983), l.

（9）金・ほか 5 名，第 5 回内燃機関合同シンボジウム椌演論文 旇, (昭 60), 253.

（10）山口・ほか6 名，自動車技術会請汿前刷集，861（昭 61）, 283.

(11) Ohta, M. and Okayama, S., Proc. 1983 ASME-JSME Thermal Eng. Joint Conf., (1983), 269.

(12) Varde, K. S., SAE Paper, 831354 (1983), 1.

(13) Bro, K. and Pederen, P. S., SAE Paper, 770794 (1977), 1.

（14）例えば，㱜田・秋田，燃烧概論，(昭 57)，28，コロナ社。

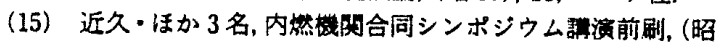
55), 139.

\section{討 論}

【胙间〕神本 武 征(東京工業大学工学部〕

（1）高負荷域でメタノール分解ガスを増した場合 の燃料消费率の向上は排熱回収によると述へでおられ るが等容度が增したためではないのか。

（2）メタノール分解ガスを混入した場合，騷音が 增すのてはないのか.

（3）貫方式の適用筑囲の図で低負荷域での領域は もっと狭いのではないか。

〔回答〕（1）図6のシリンダ内圧力経過と熱発 生率の測定例に示したとおり，メタノール分解ガスの 混入により等容度はやや上昇している。この実験装置 で，排熱回収効果と等容度の上昇効果とを敩密に分
離することは難しいのだが,ここでは図 2 あるいは表 1 の反応器の性能から見程もれる排熱回収効果が熱消 黄梁の改善俌とほほ一致することを述へている。

（2）騒音測定は行っていない。しかし，図5の最 高圧力や最大圧力上昇率の測定颠がメタノール分解が スの混入により増加することから，ご指摘のとおり騒 音が増すと考えている.

（3）ここで使用した夷験機関とその運転条件で は、ご指摘のとおりである．機䦐の圧縮比を高めたり， 排気温度のやや高い条件で運転すれば，概念図に示し たようになると考えている。 